\title{
PENGARUH INVESTMENT OPPORTUNITY SET (IOS) DAN KEPEMILIKAN MANAJERIAL TERHADAP NILAI PERUSAHAAN PADA PERUSAHAAN PROPERTY DAN REAL ESTAT DI BURSA EFEK INDONESIA
}

\author{
Nurul Hidayah \\ Fakultas Ekonomi dan Bisnis Universitas Mercu Buana \\ Email: nurulhidayah2992@gmail.com
}

\begin{abstract}
This study aimed to: determine the effect of Investment Opportunity Set used price proxy (CAPBVA) and Investment Proxy (MVBVE) and Managerial Structure on Company Value at Property and Real Estate Company listed on the Indonesia Stock Exchange in 2010-2013. The research method used is causal. Sampling method used purposive sampling with 120 data from 30 Property and Real Estate company listed in IDX. Dependent variable and independent variables measured by the ratio scale. Data analysis was performed by multiple linar regression include descriptive analysis, Classic Assumtion and Hipothesis Test. The results of these research are independent variables IOS (CAPBVA and MVBVE) significant effect on Company Value, while Managerial Structure no significant effect on Company Value.
\end{abstract}

Keywords: IOS, CAPBVA, MVBVE, Managerial Structure, Company Value.

\begin{abstract}
Abstrak: Penelitian ini dilakukan untuk menganalisa pengaruh Investment Opportunity Set (menggunakan proksi harga CAPBVA dan Proksi Investasi MVBVE) dan Kepemilikan Manajerial Terhadap Nilai Perusahaan pada Perusahaan Property dan Real Estat yang terdaftar di Bursa Efek Indonesia tahun 2010-2013. Penelitian ini menggunakan metode kausal. Sampel penelitian menggunakan metode perposive sampling dengan jumlah data 120 sampel daro 30 perusahaan Property dan Real Estat yang terdaftar di Bursa Efek. Variabel dependen dan independen diukur dengan skala rasio. Analisa data menggunakan Regresi Linear Berganda dengan melalui uji statistic deskriptif, uji asumsi klasik dan uji hipotesis. Hasil dari penelitian ini menunjukkan bahwavariable independen yaitu IOS (CAPBVA dan MVBVE) berpengaruh signifikan terhadap nilai perusahaan, sedangkan variable kepemilikan manajerial tidak berpengaruh signifikan terhadap Nilai Perusahaan.
\end{abstract}

Kata kunci: IOS, CAPBVA,MVBVE ,Kepemilikan Manajerial, Nilai Perusahaan.

\section{PENDAHULUAN}

Nilai perusahaan dapat ditunjukkan dalam laporan keuangan perusahaan khususnya laporan posisi keuangan perusahaan yang berisi informasi keuangan masa lalu dan laporan laba rugi untuk menilai laba perusahaan yang diperoleh dari tahun ke tahun. Sementara dipihak lain ada yang beranggpan bahwa nilai perusahaaan bukan sekedar dari laporan keuangan saja melainkan nilai perusahaaan dinilai berdasarkan nilai sekarang dari aktiva yang dimiliki perusahaan dan nilai investasi perusahaan yang akan dikeluarkan di masa mendatang. Penilaian prestasi perusahaan sendiri dapat dilihat dari beberapa faktor, selain 
peningkatan perolehan laba yang menunjukkan indikator kemampuan perusahaan dalam memenuhi kewajibannya kepada para Investor, pemegang saham dan lainnya.Nilai perusahaan juga mencerminkan kekayaan atau asset yang dimiliki oleh perusahaan.Nilai perusahaan yang baik akan menarik minat pihak luar untuk bergabung dengan perusahaan. Penelitian faktor-faktor yang mempengaruhi terhadap nilai perusahaan telah di lakukan oleh Miller dan Modigliani (1960) yang menunjukkan hasil bahwa nilai perusahaan di tentukan oleh earning power dari asset perusahaan.Hubungan positip terjadi dengan semakin tinggi earning power maka akan semakin efisien perputaran asset dan profit margin akan tinggi

Investment Opportunity Set (IOS) merupakan pilihan kesempatan investasi masa depan yang dapat mempengaruhi pertumbuhan aktiva perusahaan atauproyek yang memiliki net present value positif. Sehingga IOS memiliki perananyang sangat penting bagi perusahaan karena IOS merupakan keputusan investasidalam bentuk kombinasi dari aktiva yang dimiliki (assets in place) dan opsiinvestasi di masa yang akan datang, dimana IOS tersebut akan mempengaruhinilai suatu perusahaan (Pagalung, 2003).Menurut Gaver dan Gaver (1993), IOS merupakan nilai perusahaan yang besarnya tergantung pada pengeluaran-pengeluaran yang ditetapkan manajemen dimasa yang akan datang, yang pada saat ini merupakan pilihan-pilihan investasiyang diharapkan akan menghasilkan return yang lebih besar. Smith dan Watts(1992) (dalam Wah, 2002) menyatakan bahwa manajemen investmentopportunities membutuhkan pembuatan keputusan dalam lingkungan yang tidakpasti dan konsekuensinya tindakan manajerial menjadi lebih unobservable, sehingga principal merasa manajemen apakah telah bertindak sesuai dengan keinginan mereka atau tidak. Penelitian Rachmawati dan Triatmoko (2007) yang menganalisis faktor-faktor yang mempengaruhi kualitas laba dan nilai perusahaan.Hasil penelitiannya membuktikan bahwa IOS berpengaruh positif terhadap nilai perusahaan.Kallapur dan Trombley (2001) menyatakan bahwa kesempatan investasi perusahaan merupakan komponen penting dari nilai pasar. Hal ini disebabkan Investment Opportunity Set (IOS) atau set kesempatan investasi dari suatu perusahaan mempengaruhi cara pandang manajer, pemilik, investor dan kreditor terhadap perusahaan.

Menurut Herdinata (2007), perusahaan-perusahaan di Indonesia memiliki karakteristik yang tidak berbeda dengan perusahaan-perusahaan di Asia pada umumnya, dimana perusahaan-perusahaan masih dimiliki atau di kontrol oleh keluarga. Meskipun perusahaan berkembang dengan sangat pesat sebagai perusahaan yang dimiliki oleh masyarakat (perusahaan yang go public), namun kendali keluarga masih sangat berpengaruh.Struktur kepemilikan (kepemilikan manajerial dan kepemilikan institusional) oleh beberapa peneliti dipercaya mampu mempengaruhi jalannya perusahaan yan pada akhirnya berpengaruh pada kinerja perusahaan dalam mencapai tujuan perusahaan yaitu maksimalisasi nilai perusahaan.Wahyudi dan Pawestri (2006)menyatakan bahwa dalam memaksimalisasikan nilai perusahaan disebabkan olehadanya kontrol yang mereka miliki.

\section{KAJIAN TEORI}

Teori Agensi. Jensen danMeckling (1976) menyatakan bahwa dalamteori keagenan (agency theory), hubungan agensi muncul ketika satu orang ataulebih (principal) mempekerjakan orang lain (agent) untuk memberikan suatu jasadan kemudian mendelegasikan wewenang pengembalian keputusan kepada agenttersebut. Adanya pemisahan antara kepemilikan dan pengelolaan perusahaantersebut berpotensi 
menimbulkan konflik.Terjadinya konflik yang disebut konflikkeagenan (agency conflict) disebabkan karena adanya perbedaan kepentinganantara pihak agen dan prinsipal.Manajer (agent) secara moral bertanggung jawab untuk mengoptimalkankeuntungan para pemilik (principal), namun di sisi yang lain manajer jugamempunyai kepentingan memaksimumkan kesejahteraan mereka. Dengan demikian terdapat dua kepentingan yang berbeda di dalam perusahaan dimanamasing-masing pihak berusaha untuk mencapai atau mempertahankan tingkat kemakmuran yang dikehendaki. Sehingga ada kemungkinan besar agent tidak selalu bertindak demi kepentingan terbaik principle (Jensen dan Meckling, 1976) dalam Ujiyantho dan Pramuka, 2007).

Set Kesempatan Investasi (IOS). Menurut Myers (1997) Investment Opportunity Set (IOS) merupakan keputusan investasi dalam bentuk kombinasi antara aktiva yang dimiliki (asset in place) dan pilihan investasi yang akan datang dengan Net Present Value (NPV) positif yang akan mempengaruhi nilai perusahaan.Menurut Gaver dan Gaver (1993), IOS merupakan nilai perusahaan yang besarnya tergantung pada pengeluaran-pengeluaran yang ditetapkan manajemen di masa yang akan datang, yang pada saat ini masih merupakan pilihan-pilihan investasi yang diharapkan akan menghasilkan return yang lebih besar. Secara umum dapat dikatakan IOS menggambarkan tentang luasnya kesempatan atau peluang investasi bagi suatu perusahaan, namun sangat tergantung pada expenditure perusahaan untuk kepentingan dimasa yang akan datang. Menurut Gaver dan Gaver (1993) IOS bersifat tidak dapat diobservasi. Karena sifat IOS yang merupakan variabel tersembunyi (latent) ini mengindikasikan bahwa IOS tidak dapat diobservasi, untuk dapat mengetahui ukuran suatu IOS maka diperlukan proksi IOS yang dapat dihubungkan dengan variable lain dalam perusahaan. Proksi IOS bervariasi bentuknya dan diklasifikasi menjadi 3 jenis utama (Gaver dan Gaver 1993, Jones dan Sharma 2001, dan Kallapur dan Trombley 2001, dalam Gagaring 2003) yaitu: Proksi IOS berdasarkan harga (price-based proxies); Proksi IOS berdasarkan investasi (investment-based proxies); Proksi IOS berdasarkan varian (Variance measures).

Proksi IOS berdasarkan harga (price-based proxies). IOS berdasarkan harga merupakan proksi yang menyatakan bahwa prospek pertumbuhan perusahaan sebagian dinyatakan dalam harga pasar. Proksi IOS ini berdasarkan ide bahwa prospek pertumbuhan perusahaan parsial tergabung dalam harga saham, dan pertumbuhan akan lebih besar dari nilai pasar relative terhadap aktiva-aktiva yang dimiliki (assets in place). IOS yang didasari pada harga yang terbentuk merupakan rasio sebagai suatu aktivayang dimiliki dan nilai pasar perusahaan. Rasio-rasio ini meliputi:

a. Market Value to Book of Assets. Rasio ini mencerminkan pertumbuhan perusahaan yang dinyatakan dalam harga pasar. Rasio MV/BVA mencerminkan peluang investasi yang dimilikiperusahaan, semakin tinggirasio MV/BVA semakin besar asset perusahaan yangdigunakan oleh perusahaan, maka akan semakin tinggi nilai IOS perusahaan. Pemilihanproksi mengacu pada penelitian Anugrah (2009). Rumus MVBVA adalah:

Total aktiva-Total ekuitas+(lembar saham beredar $\times$ closing price)

Total aset

b. Market to book value of equity. Rasio ini mencerminkan bahwa pasar menilai return dari investasi perusahaan di masa depan akan lebih besar dari return yang diharapkan dari ekuitasnya (Smith dan Watts 1992, Jogiyanto 1999 dalam Julianto 2003). Berarti 
jumlah saham beredar yang dikalikan dengan harga penutupan saham sebagai penilaian pasar dibagi dengan total ekuitas perusahaan. Rumus MVBVE adalah:

Asset-Total ekuitas + jumlah lembar saham beredar x closing price

Total equitas perusahaan.

c. Tobin's $\mathrm{Q}^{2}$. Rasio ini didefinisikan sebagai nilai pasar dari perusahaan dibagi dengan replacement cost dari aset. Replacement cost yang digunakan dalam penelitian ini sama dengan yang digunakan pada penelitian Skiner (1993) dan kallapur dan Trombley (1999) (Julianto 2003). Nilai pasar ditunjukkan dalam jumlah saham beredar dikalikan dengan harga penutupan pasar, replacement cost dari aset tercermin dari total hutang dan persediaan perusahaan dikurangi aktiva lancar dibagi dengan total aktiva perusahaan.

Rumus Tobin's Q2 adalah sebagai berikut:

$$
\text { ( } \left.\sum \text { saham } X \text { closing price }\right)+T U+\text { Persd }- \text { AL }
$$

TA.

d. Earnings to price. Dari berbagai penelitian IOS, rasio EPS/Price ditemukan sebagai rasio yang tidak memiliki korelasi yang signifikan dengan realisasi pertumbuhan dan memiliki korelasi yang sangat kecil dengan pertumbuhan (Kallapur dan Trombley 1999, Sami et al., 1999 dalam Agustina 2001). Rasio ini menunjukkan laba rata-rata saham yaitu laba per saham yang dibagi dengan harga penutupan saham (Gagaring 2003).

$$
\frac{\text { laba per lembar saham }}{\text { closing price. }}
$$

e. Return on equity. Menurut Van Horn ( 1995: 59 ) ROE adalah salah satu bagian dari rasio penilaian laporan keuangan yang berguna untuk menilai seberapa besar kemampuan perusahaan untuk meningkatkan laba perusahaan dengan menggunakan modal perusahaan.

$$
\frac{\text { ROE =laba bersih }}{\text { jumlah equitas }}
$$

Proksi IOS berdasarkan investasi (investment based proxies). Proksi berbasis pada investasi menunjukkan tingkat aktivitas investasi yang tinggi secara positif berhubungan dengan nilai IOS suatu perusahaan (Kallapur dan Trombley 1999 dalam Julianto 2003).Perusahaan-perusahaan yang memiliki IOS tinggi seharusnya juga memiliki tingkatan investasi yang tinggi pula dalam bentuk aktiva yang ditempatkan atau yang diinvestasikan untuk waktu yang lama dalam suatu perusahaan.Proksi ini berbentuk suatu rasio yang membandingkan suatu pengukuran investasi yang telah diinvestasikan dalam bentuk aktiva tetap atau suatu hasil operasi yang diproduksi dari aktiva yang telah diinvestasikan (Gagaring; 2003). Proksi IOS berbasis investasi di antaranya adalah:

a. Rasio capital expenditure to book value assets. Rasio ini menunjukkan adanya aliran tambahan modal saham perusahaan untuk tambahan aktiva produktif sehingga berpotensi terhadap pertumbuhan perusahaan (Julianto 2003). Hal ini ditunjukkan dengan selisih nilaiaktiva tetap perusahaan dibagi dengan total asset perusahaan. 


\author{
Ni.Buku AT t - Ni. Buku AT t-i \\ CAPBVA = -
}

b. Rasio capital expenditure to market value of assets. Rasio ini menunjukkan adanya aliran tambahan modal saham dalam perusahaan (Julianto 2003). Yakni selisih nilai aktiva tetap namun dibagi dengan jumlah dari penilaian saham dan total asset dikurangi total ekuitas perusahan.

$$
\text { CAPMVA }=\frac{(\text { Ni.Buku AT t }- \text { Ni. Buku AT t-1 })}{\text { TA-TE + }(\text { Saham X Closing Price })}
$$

c. Rasio investment to net sales. Rasio ini menggunakan investasi modal sesungguhnya sebagai suatu ukuran nilai buku gross property, plant, dan equipment.Hal ini dapat diketahui dengan menghitung investasi perusahan dibagi dengan penjualan bersih.Proksi berdasarkan investasi mengungkapkan bahwa suatu kegiatan investasi yang besar berkaitan secara positif dengan nilai IOS suatu perusahaan.Perusahaanperusahaan yang memiliki IOS tinggi seharusnya juga memiliki tingkatan investasi yang tinggi pula dalam bentuk aktiva yang ditempatkan atau yang diinvestasikan untuk waktu yang lama dalam suatu perusahaan.

$$
\begin{array}{cc}
\text { Inv.to Net Sales }= & \text { Investasi } \\
\hline----------- \\
\text { Net Sales }
\end{array}
$$

Proksi IOS berdasarkan varian (variance measures). Proksi berdasarkan varian, proksi ini mendasarkan pada ide bahwa suatu opsi akan menjadi lebih bernilai jika menggunakan variabilitas ukuran untuk memperkirakan besarnya opsi yang tumbuh, seperti variabilitas dari return yang mendasari pada peningkatan asset/aktiva (Imam dan Indra 2001). Adapun Rasio yang digunakan pada proksi berdasarkan varian ini diantaranya adalah:Variance of returns dan Assets beta. Proksi ini mengungkapkan bahwa suatu opsi yang akan menjadi lebih bernilai jika menggunakan variabilitas ukuran untuk memperkirakan besarnya opsi yang tumbuh, seperti variabilitas return yang mendasari peningkatan aktiva.

Nilai Perusahaan. Menurut Christiawan dan Tarigan (2007) ada beberapa konsep yangmenjelaskan nilai perusahaan yaitu nilai nominal, nilai intrinsik, nilai likuidasi,nilai buku dan nilai pasar.Nilai nominal adalah nilai yang tercantum secara formal dalam anggaran dasar perseroan. Nilai pasar merupakan harga yang terjadi dari proses tawarmenawar di pasar saham. Nilai buku adalah nilai perusahaan yang dihitung dengan dasar konsep akuntansi.Nilai likuidasi adalah nilai jual seluruh aset perusahaan setelah dikurangi semua kewajiban yang harus dipenuhi.Konsep yang paling representatif untuk menentukan nilai suatu perusahaan adalah konsep intrinsik.Nilai perusahaan dalam konsep nilai intrinsik ini bukan sekedar harga dari sekumpulan nilai aset, melainkan nilai perusahaan sebagai entitas bisnis yang memiliki kemampuan menghasilkan keuntungan dikemudian hari.Nilai perusahaan dalam konsep nilai intrinsik mengacu pada perkiraan nilai riil suatu perusahaan. 
Penilaian perusahaan menurut Michell (2006), bahwa penilaian tersebut mengandung unsur proyeksi, asuransi, perkiraan dan judgement. Konsep dasar penilaian, yaitu: (1) Nilai ditentukan oleh suatu waktu atau periode tertentu; (2) Nilai harus ditentukan pada harga yang wajar; (3) Penilaian tidak dipengaruhi oleh sekelompok pembeli tertentu.

Dalam jangka panjang tujuan perusahaan adalah memaksimumkan nilai perusahaan.Semakin tinggi nilai perusahaan menggambarkan semakin sejatera pula pemiliknya.Nilai perusahaan merupakan hal yang sangat diperhatikan oleh investor.

Menurut Harmono (2009:233) "nilai perusahaan merupakan ukuran nilai objektif oleh public dan orientasi pada kelangsungan hidup perusahaan”.

Dengan demikian, dapat disimpulkan bahwa nilai perusahaan merupakan persepsi investor terhadap tingkat keberhasilan perusahaan yang sering dikaitkan dengan harga saham. Nilai perusahaan lazim di indikasikan dengan price to book value (PBV). Price to book value merupakan perbandingan antara harga saham dengan nilai buku per saham Brigham dan Houston (2006:111). Rasio ini menggambarkan seberapa besar pasar menghargai nilai buku saham suatu perusahaan. Semakin tinggi rasio ini berarti pasar semakin percaya akan prospek perusahaan (Sugiono, 2009:64).

Jadi, PBV dapat diartikan sebagai hasil perbandingan antara harga saham dengan nilai buku saham. Berdasarkan perbandingan tersebut harga saham perusahaan akan dapat diketahui berada diatas atau di bawah nilai buku sahamnya. Formula untuk menghitung PBVditunjukkan sebagai berikut (Sugiono, 2009-64);

$$
\mathrm{PBV}=\frac{\text { Harga Pasar Saham }}{-------------}
$$

Kepemilikan Manajerial. Jensen dan Meckling dalam Sujoko dan Soebiantoro (2007) mengemukakan bahwa konflik keagenan terjadi karena adanya pemisahan kepemilikan dan pengelolaan. Konflik yang terjadi antara pemegang saham dan pihak manajemen tersebut tentu akan berbeda jika dalam struktur kepemilikan saham terdapat kepemilikan manajerial. Kepemilikan manajerial adalah kepemilikan saham perusahaan oleh manajer atau dengan kata lain manajer tersebut sekaligus sebagai pemegang saham (Christiawan dan Tarigan (2007). Dalam laporan keuangan perusahaan, kepemilikan manajerial ditunjukkan dengan besarnya persentase kepemilikan saham perusahaan olehmanajer. Informasi kepemilikan saham oleh pihak manajer diungkapkan dalam catatan atas laporan keuangan. Dalam teori keagenan, hubungan antara manajer dan pemegang saham digambarkan sebagai hubungan antara agent dan principal (Rachmawati dan Triatmoko, 2006). Kebijakan dan keputusan perusahaan dengan adanya kepemilikan saham oleh manajerial tentu akan berbeda dengan perusahaan tanpa kepemilikan saham oleh manajerial. Perusahan dengan kepemilikan manajerial, sebagai pemegangsaham tentunya akan menyelaraskan kepentingannya sebagai manajer danpemegang saham. Hal ini akan berbeda jika manajernya tidak sekaligus sebagaipemegang saham, kemungkinan manajer tersebut hanya mementingkan kepentingannya sebagai manajer. Kepemilikan saham manajerial akan membantu penyatuan kepentingan antara manajer dengan pemegang saham, sehinggamanajer ikut merasakan secara langsung manfaat dari keputusan yang diambil danikut pula menanggung kerugian sebagai konsekuensi dari pengambilan keputusanyang salah. Kepemilikan manajerial di hitung dengan membandingkan jumlah lembar saham yang dimiliki oleh manajer dengan keseluruhan jumlah saham yang beredar. 


$$
\% \text { saham Manajerial }=\quad \text { Jumlah lembar sahan mnj }
$$

\section{Jumlah saham beredar}

Kerangka Pemikiran. Shintawati (2011) menyatakan bahwa rasio nilai pasar ekuitas terhadap nilai buku (MVE/BVE) dapat mencerminkan adanya IOS bagi suatu perusahaan.Hasil penelitiannya menyimpulkan bahwa IOS yang diproksikan dengan MVE/BVE berpengaruh signifikan terhadap nilai perusahaan. Semakin tinggi angka rasio MVE/BVE semakin tinggi pula nilai perusahaan.Hal ini menandakan bahwa perusahaan dengan nilai pasar yang tinggi dinilai baik oleh investor melalui harga saham yang tinggi.

Pengaruh kepemilikan manajerial terhadap Nilai Perusahaan.Porsi saham yang dimiliki oleh manajerial akan mempengaruhi kebijakan perusahaan untuk memenuhi tujuan perusahaan yaitu memperoleh keuntungan bagi kemakmuran pemegang saham, untuk itu manajer harus dapat menghindari resiko yang menyebabkan pemegang saham tidak akan lagi memilih manajer yang gagal menjlankan fungsinya, dengan kebijakan manajer yang bertujuan untuk memberikan kemakmuran bagi pemegang saham dengan sendirinya akan meningkatkan nilai perusahaan. Wahyudi dan Pawestri (2006) menyatakan bahwa kepemilikan manajerial berpengaruh terhadap nilai perusahaan.Penelitian ini membuktikan bahwa proporsi kepemilikan saham yang dikontrol oleh manajer dapat mempengaruhi kebijakan perusahaan. Semakin besar proporsi kepemilikan manajemen pada perusahaan, maka manajemen cenderung akan bekerja lebih giat untuk kepentingan pemegang saham yang notabene adalah dirinya sendiri sehingga dapat meningkatkan nilai perusahaan.Kerangka Pemikiran dari uraian diatas adalah sebagai berikut:

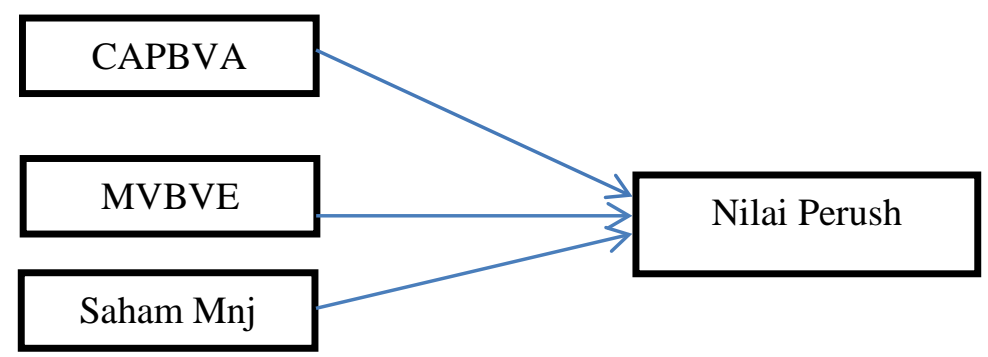

\section{METODE}

Metode penelitian yang digunakan dalam penelitian ini adalah penelitian kausal, dalam hal ini variable independen yaitu Set Kesempatan Investasi (Proksinya MVBVE dan CAPBVA) dan Struktur Kepemilikan Manajerial. Variabel dependent Nilai Perusahaan yang diproksi dengan Price to Book Value.

Populasi adalah perusahaan yang terdaftar dalam kelompok perusahaan property dan Real Estate di Bursa Efek Indonesia sebanyak 40 perusahaan.Metode pengambilan sampel yang digunakan dalam penelitian ini adalah metode purposive sampling sesuai dengan kriteria yang ditentukan.Dan sampel yang memenuhi kriteria dalam penelitian ini sebanyak 30 perusahaan, dengan tahun pengamatan 4 tahun, maka jumlah sampel 120 perusahaan. 
Metode yang digunakan dalam penelitian ini adalah: (1) Deskriptif Statistik. Deskriptif statistik adalah statistik yang berfungsi untuk mendeskriptifkan atau memberi gambaran terhadap objek yang diteliti melalui sampel. (2) Uji Asumsi Klasik. Uji asumsi klasik bertujuan untuk mendeteksi adanya penyimpangan asumsi klasik pada persamaan regresi berganda. Proses pengujian asumsi dilakukan bersama dengan proses uji regresi, sehingga langkah-langkah yang dilakukan dalam pengujian asumsi klasik menggunakan langkah kerja yang sama dengan uii regresi. Uji asumsi klasik terdiri dari: Normalitas Data, Uji Multikolinearitas, Uji Autokorelasi, Uji Heteroskedastisitas, dan Uji Autokorelasi. (3) Uji Hipotesis. Uji Hipotesis terdiri dari uji Koefisien Determinasi $\left(\mathrm{R}^{2}\right)$, Uji signifikansi $\mathrm{F}$ (kesesuaian model), dan Uji signifikansi t (parsial). (4) Uji Model Regresi Linear Berganda. Model regresi linear berganda digunakan untuk mengukur hubungan dua variable atau lebih juga untuk menunjukkan pengaruh antara variabel dependen dan variable lndependen. Adapun model koefisien regresi berganda adalah sebagai berikut:

$$
\mathrm{Y}=\mathrm{a}+\mathrm{b} 1 \mathrm{X} 1+\mathrm{b} 2 \mathrm{X} 2+\mathrm{b} 3 \mathrm{X} 3+\mathrm{e}
$$

\section{HASIL DAN PEMBAHASAN}

\section{Analisis Deskriptif}

Tabel 1. Statistik Deskriptif

Descriptive Statistics

\begin{tabular}{lrrrrr}
\hline & $\mathrm{N}$ & Minimum & Maximum & \multicolumn{1}{c}{ Mean } & Std. Deviation \\
\hline CAPBVA & 105 &, 00000 & 1,05689 &, 0517049 &, 16056634 \\
MVBVE & 105 &, 09 & 66,13 & 4,2178 & 8,40231 \\
K.Mnj & 105 &, 00000 & 1,00000 &, 50476190 &, 502375310 \\
PBV & 105 &, 13 & 6,32 & 1,3563 & 1,09929 \\
Valid N (listwise) & 105 & & & & \\
\hline
\end{tabular}

Sumber: Bursa Efek Indonesia, diolah

Dari Tabel di atas menunjukkan nilai minimum CAPBVA adalah 0,0000 sedangkan nilai maksimum 1,0517049, rasio CAPBVA menunjukkan adanya aliran tambahan modal saham perusahaan untuk tambahan aktiva produktif sehingga berpotensi terhadap pertumbuhan perusahaan. Nilai minimum CAPBVA disimpulkan bahwa masih ada perusahaan yg belum memanfaatkan tambahan modal saham untuk meningkatkan aktiva produktifnya. Secara Rata-rata perusahaan meningkatkan tambahan modal saham sebesar 5\% . Nilai MVBVE minimal 0,09 dan maksimal 0.661 menunjukkan perolehan return investasi perusahaan dari ekuitasnya. Dengan rata-rata perolehan return dari sampel perusahaan keseluruhan adalah sebesar 42\%. Kepemilikan manajerial menunjukkan bahwa nilai minimal 0 artinya perusahan tidak terdapat kepemilikan saham manajerial sedangkan nilai 1 berarti perusahaan memiliki kepemilikan saham manajerial.Namun ratarata kepemilikan saham perusahaan sebesar 50\%, hal ini memang perusahaan property masih banyak di kuasai oleh keluarga. Sedangkan nilai PBV sebagai indikator nilai perusahaan dengan nilai minimal 0,13 , nilai maksimal 6,32 dan nilai rata-rata 1,356 menunjukkan perusahaan mampu memberikan kemakmuran bagi pemegang sahamnya. 


\section{Analisis DataUji Asumsi Klasik}

Uji Normalitas Data

Tabel 2. Uji Normalitas

One-Sample Kolmogorov-Smirnov Test

\begin{tabular}{llrrr}
\hline & & LNCAPBVA & LNMVBVE & LNPBV \\
\hline $\mathrm{N}$ & & 105 & 105 & 105 \\
Normal Parameters & Mean & $-5,8666$ &, 7378 &, 0154 \\
& Std. Deviation & 3,41433 & 1,09018 &, 78495 \\
& Absolute &, 131 &, 127 &, 055 \\
Most Extreme Differences & Positive &, 068 &, 118 &, 055 \\
& Negative &,- 131 &,- 127 &,- 055 \\
Kolmogorov-Smirnov Z & & 1,340 & 1,303 &, 563 \\
Asymp. Sig. (2-tailed) & &, 055 &, 067 &, 909 \\
\hline
\end{tabular}

a. Test distribution is Normal.

b.Calculated from data.

Dengan menggunakan metode one sample Kolmogorof-Smirnof Test, seperti ditunjukkan pada Tabel 2, semua variabel penelitian tidak berdistribusi secara normal, menurut Imam Gozali, data yang tidak terdistribusi secara normal maka perlu dilakukan transformasi data. Data pada Tabel 2 ini adalah uji Normalitas yang telah di transformasi.

Tabel 3. Hasil Uji Multikolinearitas

\begin{tabular}{|c|c|c|c|c|c|c|c|c|}
\hline \multirow[t]{2}{*}{$\overline{\text { Model }}$} & \multicolumn{2}{|c|}{$\begin{array}{c}\text { Unstandardized } \\
\text { Coefficients }\end{array}$} & \multirow{2}{*}{$\begin{array}{c}\begin{array}{c}\text { Standardized } \\
\text { Coefficients }\end{array} \\
\text { Beta }\end{array}$} & \multicolumn{3}{|c|}{ Correlations } & \multicolumn{2}{|c|}{$\begin{array}{c}\text { Collinearity } \\
\text { Statistics }\end{array}$} \\
\hline & B & $\begin{array}{l}\text { Std. } \\
\text { Error }\end{array}$ & & $\begin{array}{l}\text { Zero- } \\
\text { order }\end{array}$ & Partial & Part & Tolerance & VIF \\
\hline (Constant) & 206 & ,166 & & & & & & \\
\hline LNCAPBVA & ,051 & 022 & ,220 & ,210 & ,226 & ,219 & 990 & 1,010 \\
\hline LNMVBVE & 181 & - 068 & 252 & 242 & 257 & 251 & - 996 & 1,004 \\
\hline K.Mnj &,- 056 & 147 &,- 036 &,- 063 &,- 038 &,- 036 & (992 & 1,008 \\
\hline
\end{tabular}

Dari Tabel 3 di atas dapat disimpulkan bahwa semua variable memenuhi syarat multikolinearitas, Yaitu nilai tolerance diatas 0.1 dan nilai VIF lebih dari 1. artinya tidak terdapat multikolinearitas.

Uji Heteroskedastisitas. Dengan menggunakan hasil scatterplot seperrti ditunjukkan pada gambar 1, menunjukkan bahwa caterplot menyebar tidak beraturan, sehingga disimpulkan bahwa tidak terdapat heteroskedastisitas (terlihat pada Gambar 1).

Uji Koefisien Determinasi. Tabel 4 juga dapat ditunjukkan hasil pengujian koefisien determinasi, yang menunjukkan hasil adjusted $\mathrm{R}$ Square sebesar 0,083. Hasil tersebut diartikan bahwa variabel-variabel independen, yang terdiri dari MVBVE, CAPBVA dan kepemilikan manajerial mampu menjelaskan sebesar sebesar 8,3\% dari variabel PBV, sedangkan sisanya sebesar $89 \%$ dijelaskan oleh variabel lain di luar model yang dianalisis, seperti variable Ukuran Perusahaan, kepemilikan publik, dan lain-lain. 


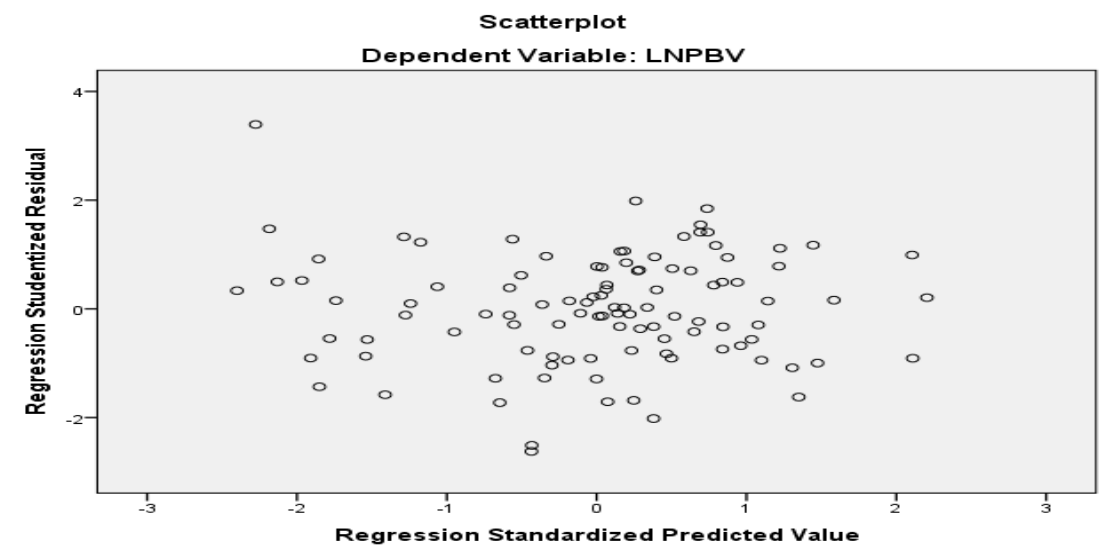

Gambar 1. Hasil Uji Heteroskedastisitas

Sumber: Bursa Efek Indonesia, diolah

Uji Autokorelasi. Dalam pengujian autokorelasi, dari Tabel 4, terlihat nilai DurbinWatson $=2,129$, terletak antara 1,54 -2,46, dapat disimpulkan tidak terdapat autokorelasi.

Tabel 4. Uji Autokorelasi

\begin{tabular}{|c|c|c|c|c|c|c|c|c|c|c|}
\hline \multicolumn{11}{|c|}{ Model Summary } \\
\hline \multirow[t]{2}{*}{ Model } & \multirow[t]{2}{*}{$\mathrm{R}$} & \multirow{2}{*}{$\begin{array}{c}\mathrm{R} \\
\text { Square }\end{array}$} & \multirow{2}{*}{$\begin{array}{l}\text { Adjusted } \\
\text { R Square }\end{array}$} & \multirow{2}{*}{$\begin{array}{c}\text { Std. } \\
\text { Error of } \\
\text { the } \\
\text { Estimate }\end{array}$} & \multicolumn{5}{|c|}{ Change Statistics } & \multirow{2}{*}{$\begin{array}{l}\text { Durbin- } \\
\text { Watson }\end{array}$} \\
\hline & & & & & $\begin{array}{c}\text { R Square } \\
\text { Change }\end{array}$ & $\begin{array}{c}\text { F } \\
\text { Change }\end{array}$ & df1 & df2 & $\begin{array}{c}\text { Sig. F } \\
\text { Change }\end{array}$ & \\
\hline 1 &, $331^{\mathrm{a}}$ & ,110 & ,083 & ,75164 & ,110 & 4,141 & 3 & 101 & ,008 & 2,129 \\
\hline
\end{tabular}

Sumber : data diolah dari BEI

a. Predictors: (Constant), K.Mnj , LNMVBVE, LNCAPBVA

b. Dependent Variable: LNPBV

Uji Ketepatan Model. Uji ketepatan model identik dengan uji hipotesis secara bersamasama. Dianalisis dengan menggunakan hasil dari perhitungan Anova. Dengan melihat signifikansi yang kurang dari 0,05, menunjukkan bahwa secara bersama-sama variabel independen yang terdiri dari MVBVE, CAPBVA dan kepemilikan manajerial berpengaruh secara signifikan terhadap variabel $\mathrm{PBV}$ atau dapat dikatakan bahwa model yang digunakan adalah sudah tepat.

Tabel 5. Uji Ketepatan Model

ANOVA $^{\mathrm{a}}$

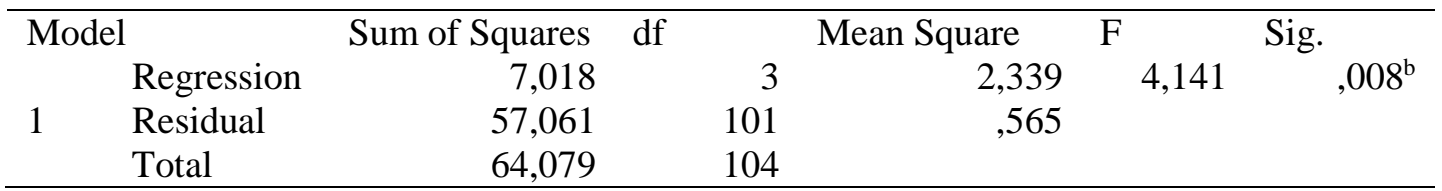

a. Dependent Variabel: LNPBV

b. Predictors: (Constant), K.Mjn, LNMVBVE, LNCAPBVA

Sumber: Bursa Efek Indonesia di olah 
Dari Tabel 6 menunjukkan bahwa variable CAPBVA dan MVBVE berpegaruh positip dan signifikan terhadap Nilai Perusahaan dengan signifikansi sebesar 0,022 dan 0,009, sementara Kepemilikan manajerial tidak berpengaruh positip terhadap nilai Perusahaan ditunjukkan dengan nilai signifikasi sebesar 0,703. Nilai tersebut diatas nilai signifikansi 0.05 .

\section{Uji Hipotesis (Uji t )}

Tabel 6. Hasil Perhitungan Pengujian Hipotesis

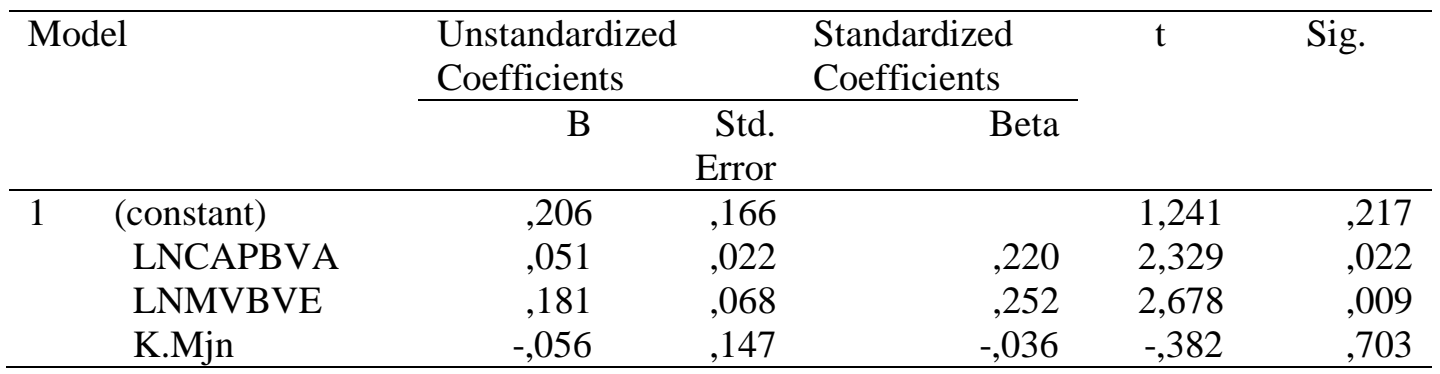

Sumber: Bursa Efek Indonesia, diolah

Uji Regresi Linear Berganda Dari Tabel 6 dapat pula disimpulkan untuk uji Regresi Linear Berganda, dengan hasil sebagai berikut:

$$
\text { Ni.Perush = 0,206 + 0.051 CAPBVA + 0.181 MVBVE - 0,056 K.Mnj }
$$

Koefisien regresi CAPBVA sebesar 0,051, artinya bahwa jika CAPBVA meningkat sebesar 1 persen, berpengaruh kepada peningkatan Nilai Perusahaan yang di proksikan dengan PBV sebesar 0,051\%. Koefisien regresi MVBVE sebesar 0,181, artinya bahwa jika MVBVE meningkat sebesar 1 persen, berpengaruh kepada peningkatan Nilai Perusahaan (PBV) sebesar 0,181\% dan koefisien regresi untuk kepemilikan sebesar minus 0,056 artinya jika terdapat kenaikan Kepemilikan Manajerial sebesar 1\% justru akan menurunkan nilai perusahaan.

Pengaruh Invesment Opportunity Set (IOS) terhadap Nilai Perusahaan. Invesment Opportunity set yang diproksikan dengan CAPBVA dan MVBVE berpengaruh positif dan signifikan terhadap nilai perusahaan, menunjukkan perusahaan mampu mengelola tambahan modal saham perusahaan untuk meningkatkan aktiva produktif sehingga berpotensi dalam meningkatkan pertumbuhan perusahaan. MVBVE berpengaruh positif dan signifikan terhadap nilai perusahaan Hal ini menandakan bahwa perusahaan dengan nilai pasar yang tinggi dinilai baik oleh investor karena dapat memberikan return yang baik melalui harga saham yang tinggi. Penelitian ini mendukung penelitian Shintawati (2011) menyatakan bahwa rasio nilai pasar ekuitas terhadap nilai buku (MVE/BVE) dapat mencerminkan adanya IOS bagi suatu perusahaan.Hasil penelitiannya menyimpulkan bahwa IOS yang diproksikan dengan MVE/BVE berpengaruh signifikan terhadap nilai perusahaan. Makin tinggi angka rasio MVE/BVE makin tinggi pula nilai perusahaan.Penelitian ini juga mendukung penelitian Irma Andriani (2011) yang mengemukakan bahwa pengaruh IOS terhadap nilai perusahaan signifikan namun kepemilikan manajerial tidak berpengaruh signifikan.

Pengaruh Kepemilikan Manajerial terhadap Nilai Perusahaan. Variabel kepemilikan manajerial dalam penelitian ini tidak berpengaruh signifikan terhadap nilai perusahaan, 
penelitian ini tidak mendukung penelitian Wahyudi dan Pawestri (2006) menyatakan bahwa kepemilikan manajerial berpengaruh terhadap nilai perusahaan. Semakin besar proporsi kepemilikan manajemen pada perusahaan, maka manajemen cenderung akan bekerja lebih giat untuk kepentingan pemegang saham yang notabene adalah dirinya sendiri sehingga dapat meningkatkan nilai perusahaan. Penelitian ini juga tidak mendukung penelitian Soliha dan Taswan (2002) yang menemukan hubungan yang signifikan dan positip antara kepemilikan manajerial dengan nilai perusahaan.Penelitian ini mendukung penelitian Irma Andriani (2011) mengemukakan bahwa pengaruh IOS terhadap nilai perusahaan signifikan namun kepemilikan manajerial tidak berpengaruh signifikan. Kepemilikan manajerial dalam penelitian ini tidak berpengaruh terhadap Nilai Perusahaan,menandakan bahwa perusahaan tetap akan berusaha memberikan kesejahteraan bagi pemilik saham atau investor tanpa mempertimbangkan adanya kepemilikan saham oleh manajerial. Bagi Investor akan memberikan keuntungan karena komitmen perusahaan untuk meningkatkan nilai perusahaannya.

\section{PENUTUP}

Simpulan. Berdasarkan hasil penelitian yang menggunakan data dalam kurun waktu 2010-2013 dengan objek penelitian perusahaan Property dan Real Estat, maka dapat ditarik simpulan sebagai berikut: (1) Variabel Invetment Opportunty Set yang di Proksikan dengan rasio CAPBVA (Capital Expenditure to Book Value Assets) yang merupakan Proksi IOS Investasi dan MVBVE (Market to book value of equity), diperoleh kesimpulan bahwa ke dua variabel tersebut berpengaruh positip dan signifikan terhadap Nilai Perusahaan; (2) Variabel Kepemilikan Manajerial dalam penelitian ini terbukti tidak berpengaruh sigifikan terhadap Nilai Perusahaan.

\section{DAFTAR RUJUKAN}

Andriyani, Irma (2011) Pengaruh IOS dan Mekanisme Corporate Governance terhadap Kualitas Laba dan Nilai Perusahaan. Undip.

Andri Rachmawati, Hanung Triatmoko, (2007) Analisis Faktor-Faktor yang mempengaruhi Kualitas Laba dan Nilai Perusahaan. SlA Makasar 2007, Univ. Sebelas Maret.

Anti Dwi Putriani, (2009) "Analisis Pengaruh IOS terhadap Return Saham Perusahaan Manufaktur”, Artikel . Universitas Gunadarma.

Brigham, Eugene F., dan Houston, Joel. (200l) Menajemen Keuangan, Buku IL Edisi Kedelapan. lakarta: Erlangga.

Christiawan, Yulius Jogi dan Iosua Tarigan. (2009) Kepentilikan Manajerial; Kebijakan Hutang,Kinerja dan Nilai Perusahaan. http://www.petra.ac.id. 23 Juni.

Fajrul Marinda,Zulkirorn,saifi (2014) ”Pengaruh IOS dan Struktur Modal terhadap Kineria Keuangan”, JurnalAdministrasi clan Bisnis (JAB) vol l Sept.20ll.

Fakhruddin, M dan HM. Sopian. (2001) Perangkat darr Model Anatisis Investasi Di pasar Modal. Buku l.Jakarta; Elex Media Komputindo.

Gaver, J.J, dan Gaver, K.M. (1993) “Additional Evidence on The Association Between The Irrvestment OpporlLrnity Set ar,d Corporate Financing Dividend, and Compesation Policies”, Jouynal ofAccounting and Economic. pp. 125-160. 
Herdinata, Cristian. (2007) "Hubungan antara struktur kepemilikan, corporate governance, dan nilai perusahaan yang go public di Bursa Efek Indonesia”. Jurnal Manajemen PPM,7 Nov 2007.

Hartono, Jogiyanto. (2008) Teori Portfblio dan Analisis Investasi.Yogyakarta. BPFE UGM.

Husnan S, (2008) Manajernen Keuangan-Teori dan Penerapan (Keputusan Jangka Panjang. Buktt I Edisi Keempat. Yogtakarta: BPFE.

Jensen dan Meckling, W. (1976) "Theory of the Firm: Managerial Behavior. Agency Cost and ownership Structure”, Journal of Financial Economics, 3: 305-360.

Kallapurr.S., dan Trombley, M. K (2001) The Investment Opportunity Set: Deterrninants, Consequences, and Measuremenl, Managerial Finance 27. pp.3-15.

Myers, Stewart C. (1977) “Determinant of Corporate Borrowing”, Journal of Financial Economics 5. pp. 147-175, 1984 The Cupital Structure Puzzle

Modigliani, F dan Miller, M. H. (1958) "The Cost of Capital, Corporation Finance and The Theory of Invesment", The American Economic Review, 261-297.

Ni.Gusti. Silka Pratika (20ll) "Pengaruh IOS,Leverage, dan Deviden Yield terhadap Profitabilitas dan Nilai Perusahaan”. E Jurnal Ekonomi dan Bisnis Univ. Udayana vol 2 (3), Tahun 2013.

Rachmawati, Andri dan Triatmoko Hanung. (2007) “Analisis Faktor-faktor yang Mempengaruhi Kualitas Laba dan Nilai Preusan”, SNA X, Makasar 26-28 Juti 2007

Siallagan, Hamonangan dan Machfoedz, Mas'ud. (2006) "Mekanisme Corporate Governance, Kualitas Laba Dan Nilai Preusan”. Simposium Nasional Akuntansi IX. Padang

Scott, William R. (2011) Financial Accounting Theory, 6th Edition, USA: Prentice Hall.

Soliha, Euis \& Taswan. (2002) "Pengaruh Kebijakan Hutang Terhadap Nilai Perusahaan serta Beberapa Faktor yang Mempengaruhinya”, Jurnal Bisnis dan Ekonomi Vol. 9, p 149 STIE STIKLIBANK, Semarang.

Sujoko \& Soebiantoro, Ugy (2007) "Pengaruh Struktur Kepemilikan Saham,Leverage, Faktor Intern dan Faktor Ekstern Terhadap Nilai Perusahaan“, Jurnal Manajemen dan Kewirausahaan Vol 9 (1),Universitas Kristen Petra, Surabaya.

Putu Terestiani Dadri (2011) "Pengaruh Investment Opportunity Set Dan Struktur Modal Terhadap Return Saham Pada Perusahaan Farmasi Di Bursa Efek Indonesia”, Tesis Universitas Udayana .

Wahyudi, Untung dan Pawestri, Hartini Prasetyaning. (2006) "Implikasi Struktur Kepemilikan Terhadap Nilai Perusahaan: Dengan Keputusan Keuangan sebagai Variabel Intervening”, Simposium Nasional Akuntansi 9. Padang 